\title{
10. The String Figures of Yirrkala: Examination of a legacy
}

\author{
Robyn McKenzie
}

\begin{abstract}
Who's the painted cave man
Who lives in Arnhem Land

You'll find it's Fred McCarthy

Tying strings around his hand. ${ }^{1}$

— Anonymous
\end{abstract}

When the 1948 American-Australian Scientific Expedition to Arnhem Land was all but over and the party was taking stock in Darwin, Howell Walker, the National Geographic Society writer-photographer, asked each participant to respond to two questions: 'What did they consider the most significant contribution to their field that the Expedition had made possible?'; and 'What would their respective home institutions consider the most valuable work done by the Expedition?'

Frederick McCarthy, one of three ethnographic researchers on the Expedition (alongside Frank Setzler from the Smithsonian Institution and Charles Mountford, the Expedition leader), not surprisingly stated that the 'collection of specimens' of material culture and natural history would be most valued by his institution, the Australian Museum. For the most significant contribution to the field of anthropology, he nominated the archaeological survey he carried out in collaboration with Setzler (see Clarke and Frederick, this volume). He gave equal standing to the collection of string figures he made at Yirrkala: 'a record number... from one group of natives.' McCarthy described it as 'the most complete study of string-figures yet made in one area in Australia' and noted that it 'increases the total to three times as many [as] previously known in the whole of the continent'. ${ }^{2}$

McCarthy's collection of string figures - constituting by his estimate one-fifth of all 'known' string figures in the world at the time-remains the largest of

\footnotetext{
1 Author unknown, stanza of a ditty/song/poem, typewritten and pasted into McCarthy's diary on 24 July. F. D. McCarthy, 1948, Diary 4, Yirrkalla Diary No. 1 and Milingimbi, Papers of Frederick D. McCarthy, MS3513/14/4, Australian Institute of Aboriginal and Torres Strait Islander Studies (AIATSIS), Canberra.

2 The questions from Walker and McCarthy's response - both typewritten on separate sheets of paper-are pasted into McCarthy's diary opposite the entry for 12 November. F. D. McCarthy, 1948, Diary 5, Yirkalla Diary No. 2 and Oenpelli, Papers of Frederick D. McCarthy, MS3513/14/5, AIATSIS.
} 
its kind collected from one community at one time. ${ }^{3}$ Commonly referred to as a game, amusement or pastime, string figures (also known by the name 'cat's cradle') are patterns or designs made with a loop of string 'by co-ordinated movements of the fingers of both hands, assisted by the teeth, neck, elbows, knees and toes when necessary' ${ }^{4}$ While usually executed by a single person, some require two or more participants.

McCarthy's documentation consisted of three principal (separate but complementary) components: mounted figures, textual records and photographs. There are 193 mounted figures in the Cultural Collections of the Australian Museum. Made with lengths of industrially manufactured string (knotted to form a loop), the majority of the figures were fashioned by McCarthy's principal informant, Ngarrawu Mununggurr. The final design was slipped from her hands and fixed to a cardboard or brown-paper support with small pieces of tape. Ngarrawu had exceptional skill in string-figure making. She could perform figures 'step by step, in slow motion', which McCarthy found 'invaluable' for documenting the sequence of manipulations by which a figure was made. ${ }^{5}$ These 'instructions' were recorded in two dedicated notebooks. ${ }^{6}$ In the Australian Museum Archives, there are 159 photographs of Ngarrawu and two male informants, Mawalan Marika and his son, Wandjuk, demonstrating designs.

In assessing the significance of this collection as a legacy of the Expedition, it is important first to understand how it was seen within its original context. Why did McCarthy regard this collection one of the most significant anthropological achievements of the Expedition? Why did he consider it more important than the material culture collections - the bark paintings, for example - which have received the most attention? ${ }^{7}$

\footnotetext{
3 McCarthy, F. D. 1960, 'The string figures of Yirrkalla', in C. P. Mountford (ed.), Records of the AmericanAustralian Scientific Expedition to Arnhem Land.Volume 2: Anthropology and nutrition, Melbourne University Press, Carlton, Vic., p. 422. See Martin Probert's survey of museum holdings of string-figure materials: 'Museum and other institutions with string figure artefacts - an inventory of string figures mounted on card, string figures on film, string figure photographs, and recordings of string figure songs' (last revised August 2010), <http://website.lineone.net/ m.p/sf/archives.html>, accessed 1 December 2010.

4 McCarthy, F. D. 1958, 'String figures of Australia', The Australian Museum Magazine, vol. 12, no. 9, p. 279.

5 McCarthy, 'The string figures of Yirrkalla', p. 415.

6 F. D. McCarthy, 1948, Arnhem Land Expedition Diary No. 6, String-figure techniques, Yirrkalla and Oenpelli, AMS515, Australian Museum Archives, Sydney; F. D. McCarthy, 1948, Arnhem Land Expedition Diary No. 7, String-figure techniques Yirrkala, Papers of Frederick D. McCarthy, MS3513/14/6, AIATSIS.

7 See Neale, M. 1998, "Charles Mountford and the "bastard barks" — a gift from the American Australian Scientific Expedition to Arnhem Land', in L. Seear and J. Ewington (eds), Brought to Light: Australian art 1850-1965, Queensland Art Gallery, Brisbane, pp. 210-17; and May, S. K. 2010, Collecting Cultures: Myth, politics, and collaboration in the 1948 Arnhem Land Expedition, Altamira, Calif.
} 
10. The String Figures of Yirrkala

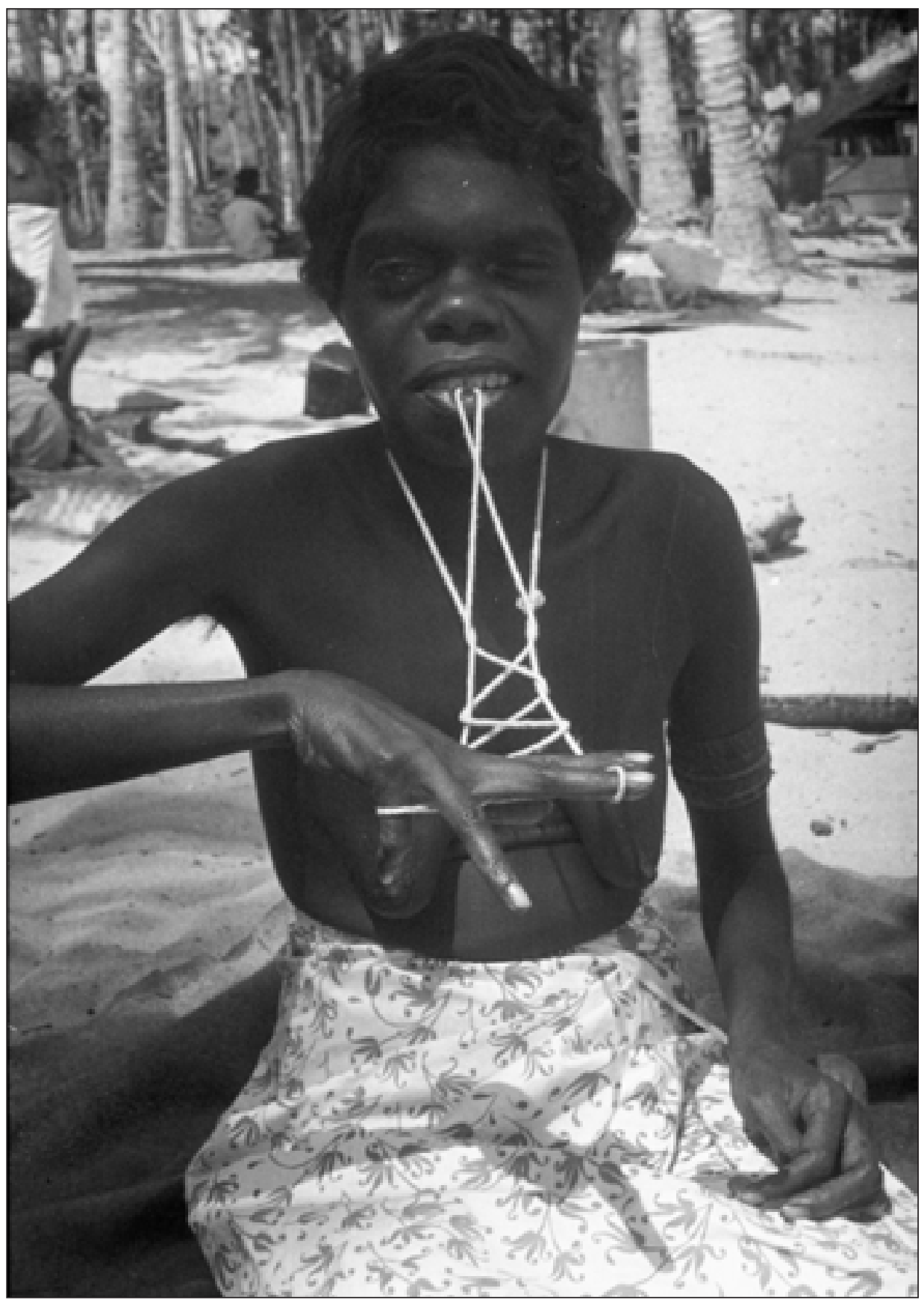

Figure 10.1 Ngarrawu Mununggurr making Lightning/Bapa string figure, Yirrkala Beach Camp, 1948

Photograph by Frederick McCarthy. By permission of Australian Museum Archives. AMS 353, Fred McCarthy Field Trip Photographs, V08961.32. 
String figures do not lend themselves to being collected in the usual sense. The whole fun of string-figure making (and its foundational ontological premise) is that you always begin and end with the dumb and inert material: the loop of string. In contrast, the constituency or 'place of being' of the string figure is in the animation of the string, and its transformation through movement or manipulation. As Dinah Eastop, a contemporary commentator, has written: 'string figures exist only in the process of "making" them.' ${ }^{8}$ We need to understand therefore what it was that McCarthy was collecting, and why. It is interesting to note in this regard that McCarthy recorded the Yolngu Matha term for string figures as 'maitka-uma' (his transcription of matjka-wuma). ${ }^{9}$ This is a compound term, combining matjka, meaning string and things made with string (including string figures and chest harnesses), and wuma, a verb meaning to do or make. ${ }^{10}$ Anthropologists and ethnologists considered the examination of games to be within the broad purview of studying a culture in its entirety. Since games were not considered of serious import, they were, however, often not accorded much time or space. String figures, however, were a special case.

\section{From Little Things Big Things Grow: Or a case of 'mild diffusionism'}

In ethnology, as in other sciences, nothing is too insignificant to receive attention. $^{11}$

— Alfred C. Haddon

Alfred C. Haddon was a major force in the development and promotion of the anthropological study of string figures. He first encountered them on his 1888 trip to the Torres Strait. ${ }^{12}$ After returning from a second tour-the

8 Eastop, D. 2007, 'Playing with Haddon's string figures', Textile, vol. 5, no. 2, p. 197.

9 In this text, I use the accepted contemporary orthography for Yolngu Matha words and personal and place names. The variant original spellings of what McCarthy referred to as 'native names' are preserved in quotations from primary sources, such as his diaries and published writing. The term 'Yolngu Matha', meaning Yolngu language, is inclusive of the different languages spoken by the Yolngu people of North-East Arnhem Land. These languages are clan based, and individuals might speak a number of different languages, depending on their clan affiliations and the context. Many words are, however, similar across language groups. McCarthy's informants would have predominantly spoken the languages of their respective clans: Djapu, Rirratjingu and Manggalili.

10 McCarthy, 1948, Diary 6, AMS515, Australian Museum Archives. The function of matjka-wuma as a compound noun+verb form was explained to me by linguist Frances Morphy (Personal correspondence, 21 October 2010).

11 Haddon, A. C. 1906, 'Introduction', in C. F. Jayne, String Figures, republished in 1962 as String Figures and How to Make Them: A study of cat's-cradle in many lands, Dover, New York, p. xi.

12 Eastop, 'Playing with Haddon's string figures', pp. 192-5; Haddon, A. C. 1890, 'The ethnography of the western tribes of Torres Straits', Journal of the Anthropological Institute of Great Britain and Ireland, vol. 19, p. 361 . 
famous Cambridge Anthropological Expedition to the Torres Strait of 1898Haddon co-wrote an article with W. H. R. Rivers (who accompanied him on that Expedition), which established a nomenclature and descriptive method for recording construction techniques for string figures. Addressing the paucity of the available information' on string figures, their object was 'to induce field workers to pay attention to the subject'. ${ }^{13}$ By specifying standard terms for fingers, loops, near and far strings, and movements, they developed a systematic basis for the 'scientific' study of string figures, enhancing the potential for comparative analysis. ${ }^{14}$ Their system of notation, with some modifications, remains the standard in use today.

In his introduction to Carolyn Furness Jayne's popular guide to String Figures (1906) (an inventory of research to that date), Haddon noted that in a number of cultures there were aspects of the practice that suggested a connection with religion and mythology. As he put it, 'we have here to do with some symbolism'.${ }^{15}$ He suggested that further research into this would be profitable. However, the primary motive of string-figure study - throughout its heyday in the first decades of the twentieth century - was determined by the 'scientific' course Haddon and Rivers had set. The recording of designs and the method of making them was the major preoccupation. The study of string figures was placed in the service of diffusionist theory, the goal of which was to map the spread of culture in time across geographic areas. ${ }^{16}$ If the same string-figure design was found to occur in different places, it was inferred that some form of contact transmission between populations had taken place. As the same figure could be made by different means, the technique or order of manipulations was considered an essential factor in making such comparative analyses, rather than the focus being on final patterns alone. ${ }^{17}$ As a later commentator explained: 'crucial affinities lie in style and procedure-distinctive openings, manipulations, extensions, and releases. ${ }^{\prime 18}$

While anthropological debates about the value of diffusionist theory and between the adherents of different diffusionist hypotheses were most heated in Britain in the 1910s and 1920s, diffusionist thinking had a longer pedigree. The historian of anthropology George Stocking has argued that before the emergence

13 Rivers, W. H. R. and Haddon, A. C. 1902, 'A method of recording string figures and tricks', Man, vol. 2, pp. 146-7.

14 Haddon, 'Introduction', p. xii; Sillitoe, P. 1975-76, 'Why string figures?', Cambridge Anthropology, vol. 3, no. 1, pp. 18-20.

15 Haddon, 'Introduction', p. xxii.

16 For a succinct discussion of diffusionism, see Kuklick, H. 2008, 'The British tradition', in H. Kuklick (ed.), A New History of Anthropology, Wiley-Blackwell, Oxford, pp. 68-9.

17 Davidson, D. S. 1941, Aboriginal Australian String Figures, republished in 2006, Hesperian Press, Carlisle, WA, p. 783.

18 Lane, B. 1963, 'On string figures: a protest', [Letter to the Editor], American Anthropologist, vol. 65, no. 4, p. 911 . 
of functionalism in the 1930s, two models of thinking alternated in dominanceboth taking a historical or diachronic perspective: 'a progressive developmental paradigm', which was evolutionist in nature; and 'a migrational or diffusionary paradigm' ${ }^{19}$ In this context, it should be noted that Haddon credited E. B. Tylor, who in 1879 gave an address on the geographical distribution of games, as the first to draw attention to the possible use of string-figure distribution to trace the migration of cultures. ${ }^{20}$

The one and only time McCarthy worked on string figures was on the Arnhem Land Expedition. This was the first of only two opportunities he had to work with living cultures in his career. ${ }^{21}$ During 30 years as head of the Department of Ethnology at the Australian Museum, he explored a broad field of topics, which could be placed under the general heading of anthropology, but his primary area of interest was in the sub-field of archaeology - in particular, the typology of stone tools and the sequencing of rock art. ${ }^{22}$ McCarthy came to the pursuit of 'the prehistory and archaeology of the Aboriginal past' through his work at the museum, where he started at a very young age. From 1932 to 1935, he undertook a part-time Diploma of Anthropology at the University of Sydney under A. P. Elkin. ${ }^{23}$ His great strengths were the description, analysis and ordering of artefacts. The Stone Implements of Australia (co-authored with E. Brammell and H. V. Noone) was published in 1946 and for years remained an unsurpassed classic. Professor John Mulvaney considered it 'the most systematic and best documented handbook on implement classification on a continental scale' ${ }^{24}$

19 Stocking, G. W. 1984, 'Radcliffe-Brown and British social anthropology', in G. W. Stocking (ed.), Functionalism Historicized: Essays on British social anthropology, University of Wisconsin Press, Madison, and London, pp. 135-6.

20 Tylor, E. B. 1880, 'Remarks on the geographical distribution of games', [paper delivered 14 March 1879], The Journal of the Anthropological Institute of Great Britain and Ireland, vol. 9, pp. 23-30. Notably in this address Tylor postulated a migration pattern from a centre of origin in South-East Asia 'westward into Europe, and eastward and southward through Polynesia and into Australia'. On Tylor's influence see, Haddon, 'Introduction', p. xx; and Sherman, M. A. 1992, 'Preface', in J. Averkieva and M. A. Sherman, Kwakiutl String Figures, University of Washington Press, Seattle, and London, p. xiv.

21 On the limited opportunities McCarthy had for this type of fieldwork, see Mulvaney, D. J. 1993, 'Sesquicentenary to bicentenary: reflections on a museologist', Records of the Australian Museum, supp. 17, pp. 17-24; and Khan, K. 1993, 'Frederick David McCarthy: an appreciation', Records of the Australian Museum, supp. 17, pp. 1-5.

22 For a discussion of the development and segmented interests of the profession, see Urry, J. 1993, “The search for unity in British anthropology, 1880-1920', in Before Social Anthropology: Essays on the history of British anthropology, Harwood Academic Publishers, Chur, Switzerland, p. 8.

23 McBryde, I. 1998, 'Frederick David McCarthy 13 August 1905 - 18 November 1997', [obituary], Australian Aboriginal Studies, no. 1, p. 52. For a comprehensive account of McCarthy's career, see Attenbrow, V. 2008, 'Ethnographic and archaeological collections by F. D. McCarthy in the Australian Museum', in N. Peterson, L. Allen and L. Hamby (eds), The Makers and Making of Indigenous Australian Museum Collections, Melbourne University Press, Carlton, Vic., pp. 472-507.

24 Mulvaney, D. J. 1980, 'Two remarkably parallel careers', Australian Anthropology, vol. 10, pp. 96-101, at p. 99; and Mulvaney, 'Sesqui-centenary to bicentenary', p. 19. 
Mulvaney has described McCarthy as having 'mildly diffusionist principles' ${ }^{25}$ In the thesis he submitted for the Diploma of Anthropology in early 1935, on Aboriginal material culture of Eastern Australia, McCarthy surveyed various theoretical arguments regarding the dynamics of cultural diffusion in Australia. ${ }^{26}$ He discussed the work of the Vienna School theorist Fritz Graebner and the British diffusionist Rivers, but gave most space to the work of the American D. S. Davidson, a follower of Carl Wissler. McCarthy had a sustained and long-term engagement with Davidson's work and through it with a strain of diffusionist thinking that went under the name 'age and area theory' or 'geographical distribution theory'. In 1936, McCarthy reviewed a series of articles Davidson had published on Australian Aboriginal material culture. His review commenced with a slab of explanation of the theory, quoted from Davidson:

This theory as its name implies, purports to reconstruct the historical development of a culture trait or complex by interpreting the chronological relationship between the relative geographical positions which the trait has successively occupied, or between the relative geographical distributions of the various differences which the trait has gone through in its historical development.

The quotation continues, giving more detail on the theory and its method. At the end, McCarthy sums up, not disapprovingly: 'From this statement of the aims of the theory, it is apparent that detailed and complete data, and a strict interpretation of the evidence are required. ${ }^{27}$

McCarthy was sympathetic to the rigours of this approach and to its aim of tracking, in effect, continuity and change in the development of culture. ${ }^{28}$ In this latter respect, his interests are not that distant from the concerns of current researchers. ${ }^{29}$ In a major article based on work he did for his dissertation, 'Aboriginal Australian material culture: Causative factors in its composition',

\footnotetext{
25 Mulvaney, 'Sesqui-centenary to bicentenary', p. 23.

26 McCarthy, F D, 1935, The Material Culture of Eastern Australia: A Study of Factors Entering into its Composition, unpublished thesis submitted for the Diploma of Anthropology, University of Sydney, pp. 123-30. Papers of Frederick D McCarthy, MS3513/17, and MS283, AIATSIS, Canberra. (There are two copies of McCarthy's thesis in the AIATSIS library: MS3513/17 is an annotated typescript, the other MS283 is a copy of this typescript with reprints of articles he published in Oceania and Mankind based on the thesis inserted.) For McCarthy's later considered views on diffusionist theory see, McCarthy, Frederick D, 1974, 'Relationships Between Australian Aboriginal Material Culture, and South-East Asia and Melanesia', in Elkin, A. P. and MacIntosh, N. W. G. (eds) 1974, Grafton Elliot Smith: The Man and His Work, Sydney University Press, pp. 210-14.

27 McCarthy, F. D. 1936, 'The geographical distribution theory and Australian material culture', [review], Mankind, vol. 2, no. 1, p. 12.

28 For an assessment of differences in thinking between McCarthy and Davidson, see Konecny, T. 1993, 'Ethnographic artefacts: the iceberg's tip', Records of the Australian Museum, supp. 17, pp. 45-6.

29 See Attenbrow, 'Ethnographic and archaeological collections by F. D. McCarthy in the Australian Museum', p. 497: 'patterns of diffusion and patterns of chronological change...these are still questions and themes being addressed by today's researchers.'
} 
published over two editions of Mankind in 1940, McCarthy wrote: 'the material culture of the aborigines has not remained static...The aborigines have experimented with many aspects of their culture, and in the adaptation to their environment have brought into play a great deal of ingenuity, resource and skill.' In his analysis of the 'causes of local variation', he recognised such factors as 'elaboration' - the development of locally unique forms (of a widespread feature, usually a customary way of doing something); 'invention' the contributions made by individual craftsmen; and 'diffusion and trade' the spread of influences between people within a local area. ${ }^{30}$ The significant difference between McCarthy and contemporary researchers is primarily the product of the scale of the project - the big idea, the encyclopedic frame, the large map - which he and his colleagues were trying to fill. When it came to plotting external influences on the development of Australian Aboriginal culture - 'the line of demarcation between introduced and indigenous traits' he argued that there were problems that would not be 'satisfactorily settled' until 'a complete distributional analysis has been made of all traits in Australia and neighbouring cultures'. ${ }^{31}$

McCarthy was a late addition to the Expedition. His inclusion was not finally confirmed until early February 1948 - a little more than one month before departure. In a letter to Mountford written at that time, he reported that he had been 'reading up the string figures' but was finding 'the technique extremely difficult to follow' ${ }^{32}$ It is possible, given this correspondence, that the idea of making a collection of string figures was first suggested by Mountford, who had previously done work on them. ${ }^{33}$ But the project would have appealed to McCarthy's sense of professional purpose. As he told himself in his diary: 'There is no complete collection from Arnhem Land in existence. ${ }^{\prime 34}$

On the Expedition, McCarthy was involved in collecting material culture artefacts, excavating archaeological sites, and documenting rock art as well as recording string figures. Opportunities for observational fieldwork (of 'the making and use of objects') were limited by the routines of life at the mission stations where the Expedition set up base camps. ${ }^{35}$ No matter how we might wish to classify his various pursuits, there is a sense they were all one and the same

\footnotetext{
30 McCarthy, F. D. 1940, 'Aboriginal Australian material culture: causative factors in its composition', Mankind, vol. 2, no. 8, pp. 242, 244-50.

31 Ibid., p. 258.

32 McCarthy to Mountford, 4 February 1948, Papers of Frederick D. McCarthy, MS3513/14/8, AIATSIS.

33 McCarthy, 'The string figures of Yirrkalla', p. 422. In his published report in the records of the Expedition, in summarising the work done on string figures in Australia up until 1948, McCarthy includes reference to the 44 figures (without techniques) Mountford collected from the Adnyamathanha tribe in the northern Flinders Ranges in 1937 and 1938 (published in 1950). See: Mountford, C. P. 1950, 'String figures of the Adnyamatana tribe', Mankind, vol. 4, no. 5, pp. 183-9.

34 McCarthy, 14 July 1948, Diary 4, AMS515, Australian Museum Archives.

35 F. D. McCarthy, 1948, Arnhem Land Expedition, Report on Scientific Work, AMS10/22/1948, Australian Museum Archives.
} 
thing for McCarthy: the gathering (collecting or describing) of ethnographic 'facts' for later analysis. The notable exception was the innovative ethnographic study of the hunter-gatherer economy done in collaboration with Margaret McArthur (see Jon Altman, this volume).

McCarthy left detailed descriptions of his process and procedures in the diaries he kept during the Expedition. Throughout these pages, his ambition of getting 'the complete' collection is apparent - the larger the number, the more complete a collection was deemed to be. His approach to collecting and recording was atomistic. He collected the bark paintings at a different time to recording their interpretations or stories; he collected the mounted figures separately from recording the techniques of making them. The objects were always collected first, and in quantity. They occupied the first column or row in his data table, providing the referent or master key for the other fields. That was their primary value. In the case of string figures, other data fields such as 'techniques of making' could be considered just as, or more, important.

In his answer to Walker's question regarding the most significant contribution made by the Expedition to the field of anthropology, McCarthy gave the reasons for his selection. He valued the archaeological survey because it was an 'untouched field' and produced 'type cultures hitherto unknown'. He valued the string figures because of the comprehensive nature of the collection: 'a record number...from one group of natives.' Interestingly, he felt the need to defend his position (which could have been seen as self-serving) with an aside as to why Mountford's collection of bark paintings and their interpretations did not rate. While finding fault with Mountford's collecting methods on Groote Eylandt, his basic argument was that collections of barks already existed from these areas. He pointed out that Ronald and Catherine Berndt had previously 'done more detailed and prolonged work' at Yirrkala and Oenpelli (now Gunbalanya). ${ }^{36}$ The string figures, like the archaeological survey, filled in blanks on the map and made original additions to the database. The barks did not.

\section{The Specimen Quest and the Time Factor: Collecting, recording and writing up}

I began collecting string-figure techniques as soon as we reached Yirrkala. ${ }^{37}$

— Frederick McCarthy

36 McCarthy, 12 November 1948, Diary 5, AMS515, Australian Museum Archives.

37 McCarthy, 1948, Diary 6, AMS515, Australian Museum Archives. 
Yirrkala, on the mainland coast, where the Expedition set up their second base camp, had been established as a Methodist mission in 1934. Most members of the 14 Yolngu clans living in the surrounding region were gradually drawn to the settlement in the following decades. ${ }^{38}$ When McCarthy arrived, he noted that a significant proportion of the local population was living beyond the settlement. 'There are 100 natives here at present but as many again are out in the bush \& at Pt. Bradshaw, Caledon Bay \& Melville Bay because of a shortage of food on the Mission.' As he described it, the settlement consisted of 'the main building', occupied by the missionaries, while 'the natives live in corrugated iron huts set in three rows on a flat to the North, \& there is an extensive garden...the site is beside a beautiful sea beach'.$^{39}$

McCarthy had been 'anxious' to start collecting string figures early in the Expedition when they were on Groote Eylandt, but was prevented from doing so by not having cardboard 'to pin them down'. ${ }^{40}$ At Yirrkala, he was conscious of the need to get off the mark quickly. He wanted to go to Milingimbi Island with Setzler to do archaeological excavations for at least a month, and to explore other sites around the hinterland of Yirrkala, so was planning to spend 'only five weeks at most' in the mission itself. McCarthy's diary for 14 July recorded his advance preparations for the work ahead. He made a list of the material culture items they required, set up the ethnographic store tent, and began to study the string figures. ${ }^{41}$

McCarthy's firsthand account of the process of his collecting - what he did when and where and with whom-is recorded in his diaries and notebooks. This commentary forms the basis for his published account in the records of the Expedition. ${ }^{42}$ Another contemporary source is McCarthy's report to his superiors at the Australian Museum. In this, he acknowledged his debt to his principal informant, Ngarrawu: 'a positive genius with a piece of string. She produced one hundred and eighty figures, all of which were photographed, mounted on card, and the techniques recorded. ${ }^{43}$ This statement implies a logical order to the activity of collecting string figures: the person makes the figure, it is photographed on their hands, mounted on card, and then the technique of

38 Caruana, W. 1997, 'The past 100 years: a brief history of the artists and their art', in W. Caruana and N. Lendon (eds), The Painters of the Wagilag Sisters Story 1937-1997, National Gallery of Australia, Canberra, p. 12; Hutcherson, G. 1998, Gong-Wapitja: Women and art from Yirrkala, Northeast Arnhem Land, Aboriginal Studies Press, Canberra, p. 1.

39 McCarthy, 9 July 1948, Diary 4, AMS515, Australian Museum Archives.

40 It was probably delayed on board the Phoenix along with the rest of the party's non-essential supplies. The Phoenix did not arrive at Umbakumba until halfway through the party's 14-week stay, by which time McCarthy was absorbed in archaeological pursuits.

41 McCarthy, 14 July 1948, Diary 4, AMS515, Australian Museum Archives.

42 McCarthy, 'The string figures of Yirrkalla', pp. 415-511.

43 F. D. McCarthy, 1948, Arnhem Land Expedition, Report on Scientific Work, AMS10/22/1948, Australian Museum Archives. 
making it is recorded. It did not, however, happen this way. The stages in the process and the three data types they relate to (photograph, mounted specimen, and textual record) were 'collected' at separate times.

McCarthy's activity can be divided into three phases. In the first of these - a two-week period from shortly after his arrival in Yirrkala to his departure for Milingimbi-he collected mounted specimens. He secured his first series (some six figures) from Mathaman Marika, one of the men with whom he had sustained contact during his time in Yirrkala. He found that Mathaman was not very good at making string figures - 'a poor manipulator' — so the next day he approached the women at the Beach Camp. Working with a small group, he collected 20 figures. Archaeological diversions took up the next two days. When he returned to the task, he worked for the first time with Ngarrawu, who was to become his principal informant. Ngarrawu Mununggurr was a young Djapu woman in her twenties from the Caledon Bay area (a granddaughter of Wonggu). Married to Nanyin Maymuru of the Manggalili clan, she had one young child at the time. She was regularly employed as a domestic by the mission, and with her co-wife, Djunbiya, had been coopted by the Expedition to work as an assistant in the Nutrition Unit's testing lab, washing bottles and doing other tasks. Kelvin Hodges and Brian Billington, who ran the lab, first alerted McCarthy to the women's skill with string figures. While McCarthy appreciated the talent of both, Ngarrawu knew a greater range of designs. ${ }^{44} \mathrm{He}$ found her 'an ideal subject with whom to work'. Ngarrawu was, he records, 'shy in manner, but always happy \& laughing' and 'a most obliging \& cheerful person' ${ }^{45}$ After returning from another archaeological excursion, he spent three solid days working with Ngarrawu, at the end of which his collection of mounted string figures had grown to 90 .

In collecting the mounted figures, after having 'exhausted those voluntarily performed' for him, McCarthy suggested subjects. ${ }^{46}$ Once the figure was made and then mounted, the support was annotated with the name of the maker, the name of the subject in English, and its Yolngu Matha name. Relevant finger positions were marked in, and sometimes the general position of the hands was sketched. In many of the mounted figures, especially those relating to animals, parts of the design were identified as representing specific features, such as head, tail, belly, and so on. It is possible from McCarthy's diary entries to estimate the time he spent collecting the mounted figures, and from that to calculate that the average time taken to collect a single specimen was approximately 20 minutes. The concentration of this activity into three half-day and four full-day sessions made this a fairly demanding pace.

44 McCarthy, 'The string figures of Yirrkalla', p. 415.

45 McCarthy, 1948, Diary 6; McCarthy, 7 September 1948, Diary 5, AMS515, Australian Museum Archives.

46 McCarthy, 'The string figures of Yirrkalla', p. 415. 


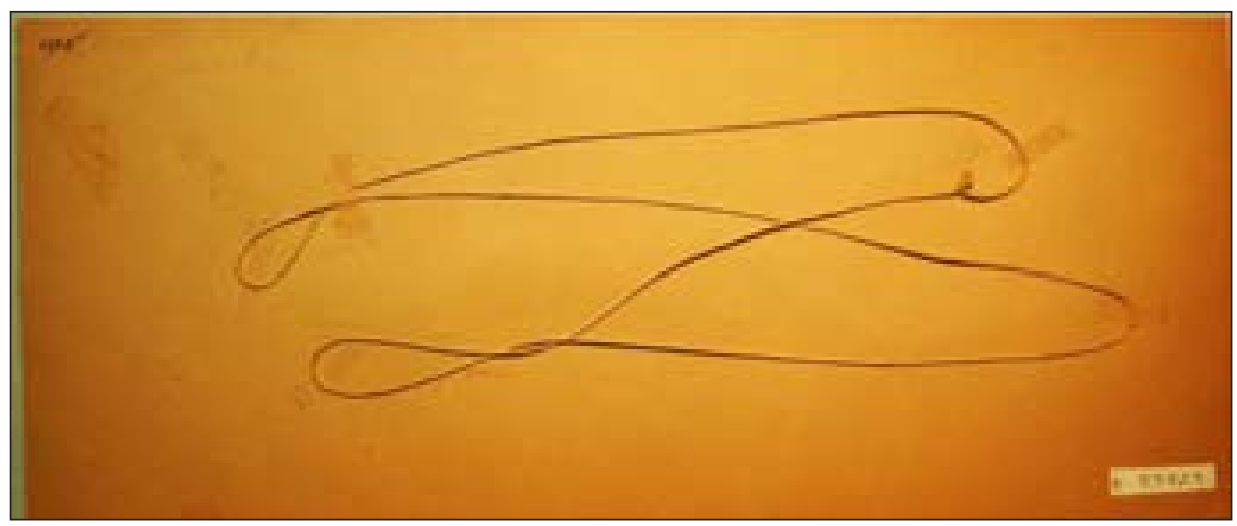

Figure 10.2 Ngarrawu Mununggurr, Wawalik sisters standing up, string figure mounted on cardboard, 1948

Photograph by Stan Florek. By permission of Australian Museum. Cultural Collections \& Community Engagement, E. 83829.

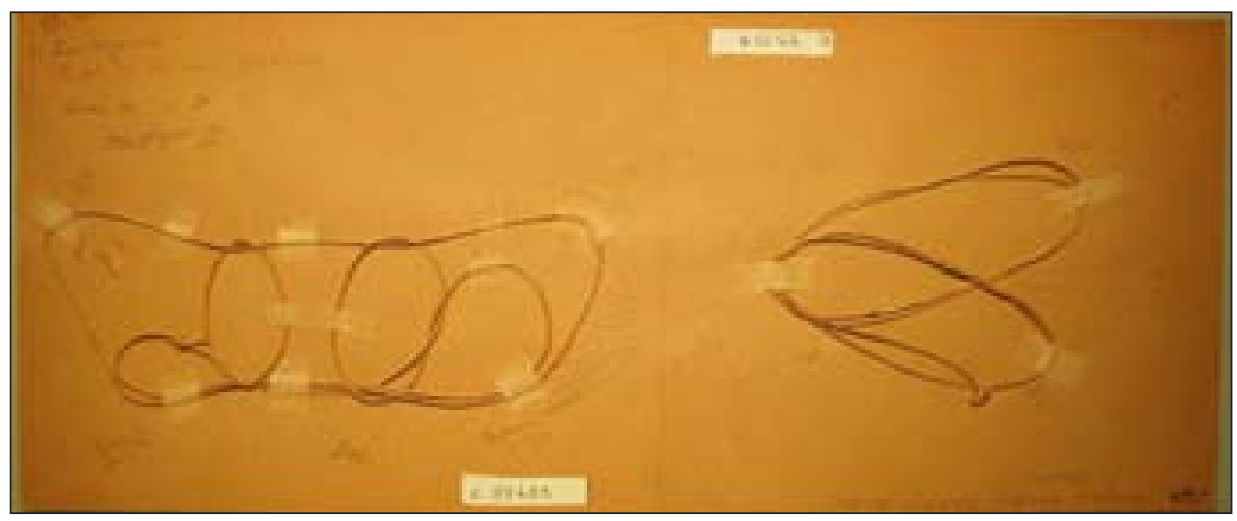

Figure 10.3 Ngarrawu Mununggurr, Two Dingoes/Wungun and Kangaroo track/Mudbia luku, string figures mounted on cardboard, 1948

Photograph by Stan Florek. By permission of Australian Museum. Cultural Collections \& Community Engagement, E. 83683 and E. 83754.

After this, McCarthy spent approximately three weeks at Milingimbi (see Louise Hamby, this volume). When he returned to Yirrkala on 20 August, he learnt that the Expedition was due to depart for Oenpelli in less than two weeks, leaving 'very little time for recording the string figure techniques' ${ }^{47}$ McCarthy spent part of the next four days working with Ngarrawu recording instructions for making the string figures he had collected. During sessions that lasted two to three hours, they spent an average of 15 minutes on each figure. Ngarrawu's ability to accommodate the demands of McCarthy's 'methodology' was truly a feat. She could reproduce designs faultlessly, at random, on demand. ${ }^{48}$ 
During the run-up to his departure, McCarthy had competing demands on his time, including preparing the ethnological collection for transport and recording interpretations of the 70 or so barks collected from Yirrkala that he and Setzler had then to divide between their two institutions. He had obviously decided to call it a day on the string figures, with the 90 mounted specimens collected and the 65 techniques recorded, when, on Saturday, 28 August, he began to 'writeup' his findings into his notebook. It is telling that in his diary entry for that day he tallies up the numbers for the other members of the team (leaving spaces to fill for those he does not have at hand): 'Miller got his $201^{\text {st }}$ fish species on the trip, Specht has 225 species of plants from Yirrkalla, Deignan has _ species of birds on the trip, \& Johnson has species of mammals.' ${ }^{49}$

Number was a currency that all the researchers on the Expedition traded in. With the exception perhaps of the Nutrition Unit, the total numbers of things collected was the measure of their work both for themselves and others; it was always the thing cited to summarise the Expedition's achievements. The emphasis on number went beyond it being an easy way of thinking about their performance, or translating what they were doing in their particular fields to their masters, or to a lay public. It was both simpler and more complex than that. Collecting as many objects as possible was an overriding concern. Their research behaviour was acquisitive. In building these collections, they were literally gathering data, and, according to the paradigm in which they were working, building a base for furthering knowledge.

This concern with quantity was made explicit in McCarthy's diaries. When the party was advised that the boat coming to transport their gear to Oenpelli was delayed, the three activities of collecting, recording and writing up were now combined in a final spate of string-figure research. Working with Ngarrawu, he caught up on recording the outstanding techniques for the 90 mounted figures already collected, and documented new ones also. This continued for a little more than a week, by which time the new departure date was approaching. McCarthy's diary tells the story:

4 September: I continued working with Narau \& got the total of string figures to 173.

5 September: In the evening I worked with Narau \& took the total to 183 string figures.

7 September: The total now is $190 \ldots$ There are probably more to be got here \& I shall try to get ten more to make the 200 should time permit. ${ }^{50}$

49 McCarthy, 28 August 1948, Diary 5, AMS515, Australian Museum Archives.

50 Ibid. 
In this third and final phase of McCarthy's work on the string figures at Yirrkala, he began to gather and record a new and different kind of data: what he referred to as 'social background' or 'social tie-up' material. This information about customary aspects of string-figure making was told to him by male informantsprincipally, Wandjuk Marika, his father, Mawalan, and Mawalan's brother Mathaman. They described various prohibitions and lore concerning figure making, including regulations that applied differentially to men, women and children. This explained a number of McCarthy's observations - in particular, the greater expertise of women in this aspect of the culture. Whereas men used string figures in ceremony, they were an everyday activity for the women. The men and the women had different names for the figures, denoting their 'inside' and 'outside' significance, and there were a number of figures that were known and made by men or women only. The children were instructed according to these rules. $^{51}$

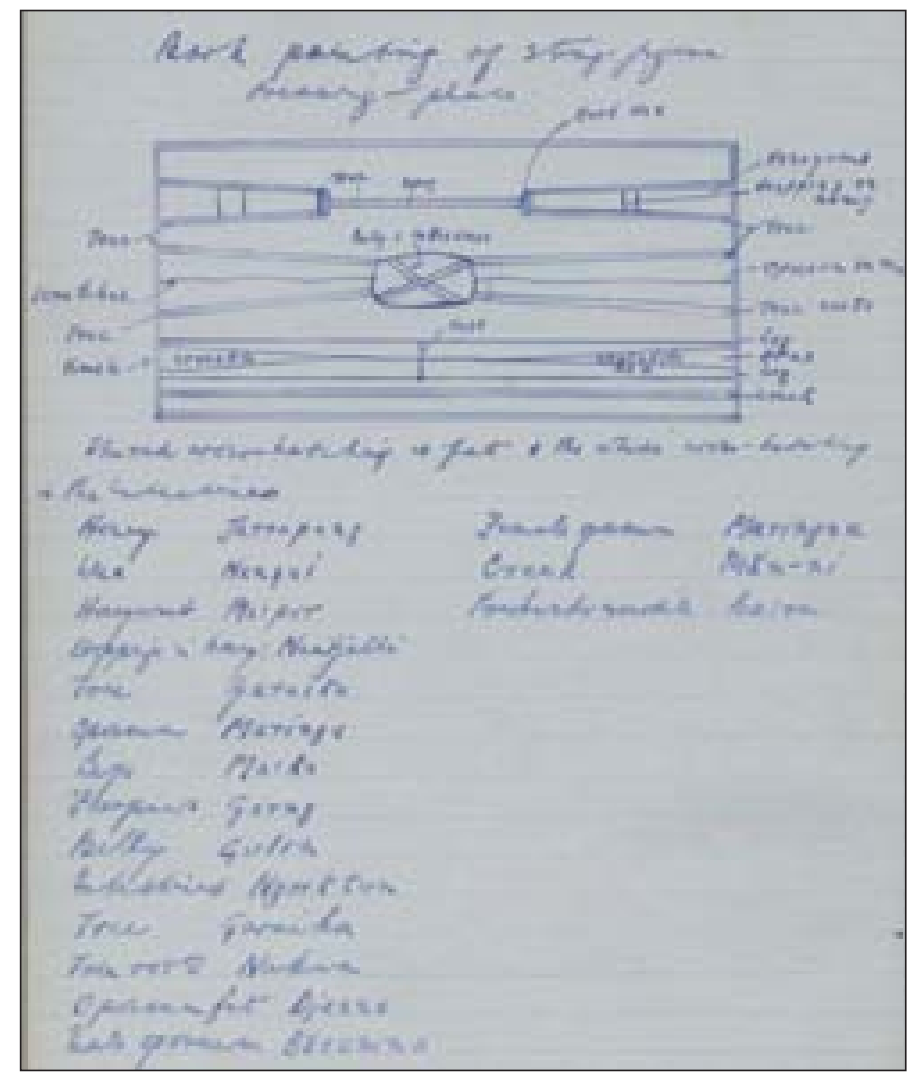

Figure 10.4 Frederick McCarthy, Bark painting of string-figure dreamingplace, documentation of a painting by Wandjuk Marika

By permission of AIATSIS, Canberra. Papers of Frederick D. McCarthy, MS3513/14/6, Arnhem Land Expedition, Diary No. 7, String-figure techniques, Yirrkala. 


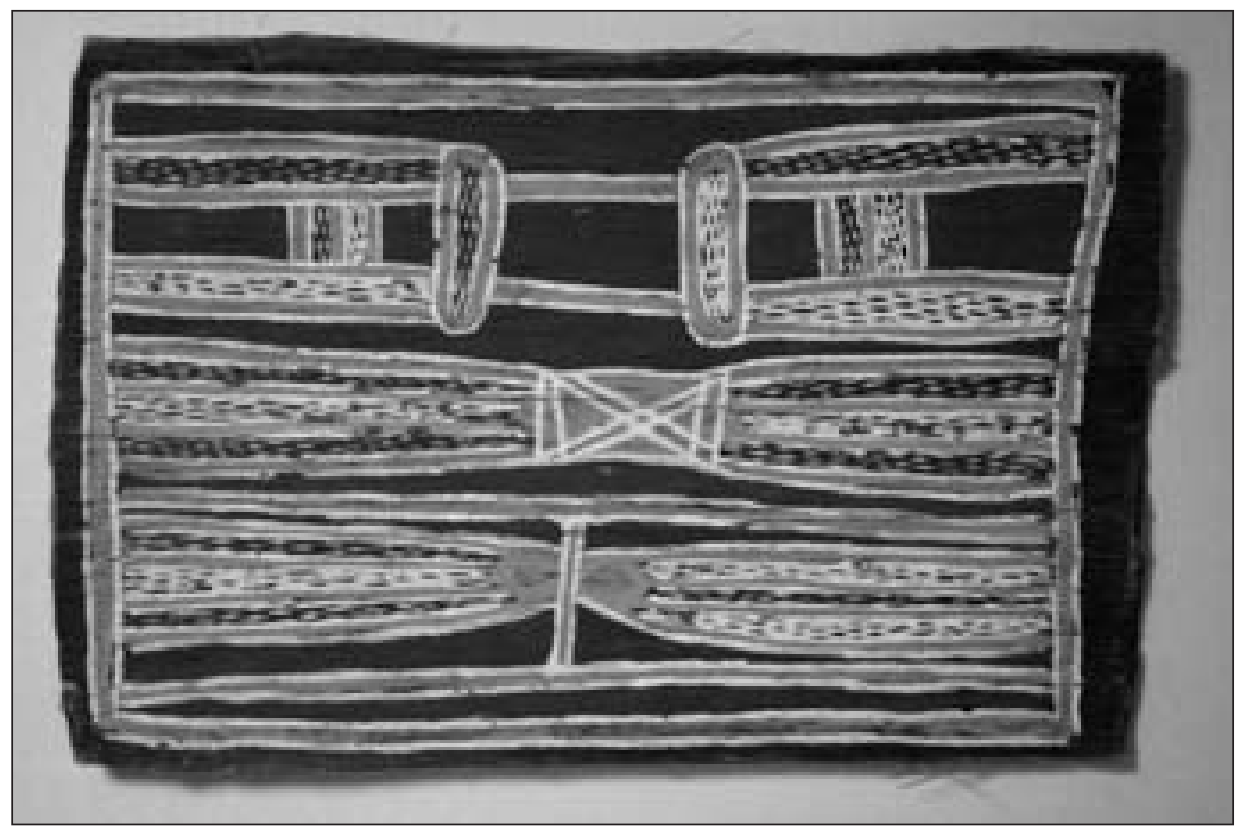

Figure 10.5 Wandjuk Marika, String-figure dreaming-place, earth pigments on bark, 1948

Photograph by Finton Mahony. By permission of Australian Museum. Cultural Collections \& Community Engagement, E.53210.

At this time, Wandjuk made for McCarthy a bark painting of 'string-figure dreaming-place'. McCarthy made a sketch of the painting in his notebook, annotating it and recording an index of Yolngu Matha names identifying the various elements represented. He recorded a number of narratives or myths involving string figures that were told to him. One of these (which he reproduced in full in the Expedition records) was an origin or creation story. It related the making of string and string figures to the well-known Wagilag Sisters myth cycle: 'String was first made by the two Wawalik sisters... [who made] a record in string of all the animals, plants and other things they saw, as well as their own activities.' In the myth, as he records it, there are 92 string figures mentioned, of which he has collected all but $16 . .^{52}$

On his last day in Yirrkala, McCarthy escaped from packing up the camp to take photographs of the string figures. His approach to this was characteristically focused. He had planned to photograph various stages in the making of the designs, but no doubt due to the time constraint, he chose to record the final stage only of the complete series. In the three hours between 9 am and noon, Ngarrawu made 149 figures for him to photograph: 'she made the next one in

52 McCarthy, 'The string figures of Yirrkalla', pp. 425-7. 
the time it took me to write down the name \& number of the previous one.' In the hour after the lunch break, she made another 40 figures. ${ }^{53}$ McCarthy then photographed Mawalan and Wandjuk making a number of the men's figures.

\section{Tying Strings Around his Hand}

It's painfully obvious that McCarthy never made a single string figure [in] his whole life. ${ }^{54}$

\section{— Mark A. Sherman}

The greater part of McCarthy's paper in the records of the Expedition consisted of instructions for making figures, accompanied by an illustration of the final form of each figure (based either on the mounted figure or on the photograph). ${ }^{55}$ They were organised, as was standard practice, according to a typology based on method of construction. Those made from the same openings were grouped together.

In 1941, D. S. Davidson had published a book based on his own field research that summarised the current state of knowledge on Australian Aboriginal string figures. McCarthy took it with him on the Expedition, and he used aspects of it as a template when writing up his data. His discussion of the 'characteristics' of the Yirrkala string figures was based on the factors Davidson had defined as significant for analysis of string figures as a 'cultural trait' - in particular, the types of manipulation and their number. ${ }^{56}$

McCarthy also described the range of subjects evident in the naming of figures, noting that 'the most important source of motives lies in the natural environment, human and animal behaviour and material culture'. Under the heading of 'Landscape and natural phenomena', for example, he lists: 'waterhole (two figures), two waterholes, water in a river-bed, ripples on a pool, running creek, crab-hole, lightning, morning star, sun, rain, clouds, granite boulders. ${ }^{.57}$ There were string figures for most things encountered in the Yolngu world. He noted that the resemblance of the designs to the subjects they represented varied considerably.

53 McCarthy, 7 September 1948, Diary 5, AMS515, Australian Museum Archives. McCarthy records in his diary taking photographs of Ngarrawu making approximately 190 figures. There are, however, only 159 photographs from this session in total in the Archives of the Australian Museum. From changes in location and the evident time of day recorded in these images, it is possible to establish the order in which they were taken, and that a roll of film (corresponding to the 40 images McCarthy records taking after lunch) is missing. 54 Mark A. Sherman to Stan Florek, 11 March 1995, Correspondence Files, Anthropology Department, Australian Museum. Mark Sherman, with Honor Maude, wrote a revision of McCarthy's instructions for making the Yirrkala figures, published in 1995.

55 Maude, H. C. and Sherman, M. A. 1995, 'The string figures of Yirrkala: a major revision', Bulletin of the International String Figure Association, vol. 2, p. 89. As they note: 'The drawings made from the mounted specimens typically do not show the hands, whereas those made from the photographs $d o .^{\prime}$

56 Davidson, Aboriginal Australian String Figures, pp. 786-91.

57 McCarthy, 'The string figures of Yirrkalla', pp. 420-1. 


\section{THE STRIVG VGTRES OF VIRRKAL.A}

\section{Wontex's Crocootte.}

1. Opening $\mathrm{A}$

2. Relene thumb loops

3. Pace right thumb over three strings, pick up near liste finger string with thumbs and return to position

4. Pick up near right index finger string with left index finger

5. Pick up near little finger string with thumbs from below and re turn to ponition

6. Insert thambs inside index finger loops and transfer

7. Navahe near thumb string with teeth on both hands

8. Release index finger loops

9. Extend

10. Pick up from below far thumb string with index fingers

11. Release thumb strings

55. Rirpens on a Poot

1. Opening $\mathbf{A}$

2. Release thumb loops

5. Place right thumb over three strings and pick up far right litule finger string with right index finger

4. Pick up near right index finger string with left index finger

5. Fxiend

6. Pick up near little finger string from below with backs of thumbs and return to position

7. Insert thumabs under near uppes index finger string

8. Navaho near lonver thumb string with tecth

9. Insert index finger in thumb loop and transfer loops to index fingers

10. Extend (pindiki)

12. Pick up from below near little finger string with thumb

13. Insert both thumbs inside index finger loops

14. Navaho near thumb string with teeth on both hands

15. Pick up near index finger string with middle fingers

16. Release thumb looph

17. Extend to figure. Size 12 by 6 inches

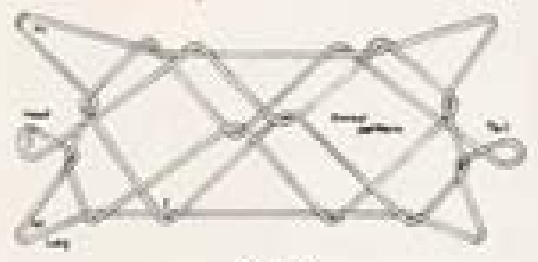

Tx. 60

11. Pick up near little finger string with thumbs and return to position

12. Insert thumbs under near upper index finger loop

13. Navaho near lower thamb string with teeth on both hands

14. Pick up near lower index finger string with mialdle fingers

15. Release far litule finger string

16. Extend to figure. Size 7 by 1 inches

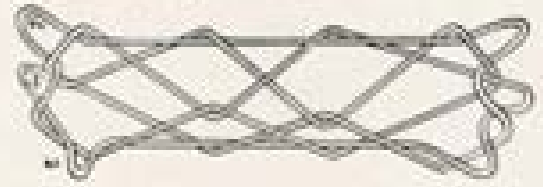

Vis. 61

\section{Crovm}

1. Opening A Sise 11 by 5 inches

2 Pull out from behind the right index finger loop with tips of left thumb and index finger

5. Repeat with left index finger loop

4. Invert left loop through right one

5. Pick up the two loops with index fingers

6. Fxiend to figure.

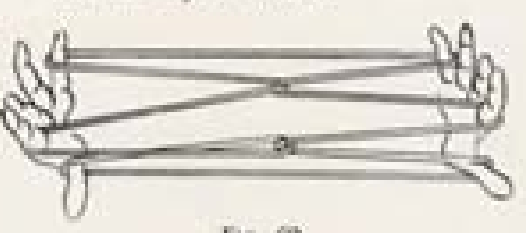

Fic. 6 465

Figure 10.6 Page from Frederick McCarthy, 'The string figures of Yirrkalla'

From C. P. Mountford (ed.) 1960, Records of the American-Australian Scientific Expedition to Arnhem Land. Volume 2: Anthropology and nutrition, Melbourne University Press, Carlton, Vic. 
Davidson argued that the making of string figures in common with many other traits' had been introduced into Australia from Melanesia via Cape York in northern Queensland. ${ }^{58}$ McCarthy was an advocate of Rivers' theory that Australia was probably visited by successive 'small bands of immigrant people arriving by chance at various points of the north Australian coastline', and that there were therefore 'a number of centres from which traits could diffuse' ${ }^{59} \mathrm{On}$ the basis that only 24 Yirrkala figures, and three of the 78 collected from Central Australia, were duplicated in records from Queensland, he concluded that Arnhem Land formed a second point of diffusion (particularly into the Northern Territory and Central Australia). Based on the limited duplications he found between the Yirrkala figures and those collected in other locations, McCarthy argued, more radically, however, that the majority of Australian figures were in fact of 'local origin'. They represented local subjects and were made using local techniques, 'developed by a people from the common basic foundation' ${ }^{60}$

Davidson had emphatically stated (while admitting it seemed strange given 'the complex social and totemic systems' in Aboriginal culture) that there was no evidence that designs had significant content or meaning. ' $[\mathrm{P}]$ ractically no patterns have been given a social, totemic or magical connotation...it would seem that string figures in Australia serve almost entirely the purpose of amusement', he wrote. ${ }^{61}$ What is singular therefore in McCarthy's report is the information he includes under the heading of 'Socio-magical regulation' - the data gathered in his last days in Yirrkala. He observed, for example, that the making of string figures provided 'a link between the women and the tribal mythology', from which they were customarily excluded when it was expressed in the form of ceremonial ritual. 'As they make the string figures the women are thinking not only of a particular animal but of its significance in the Wawalik sisters' saga,' he explained. ${ }^{62}$

While this kind of 'associated cultural data' was acknowledged as useful additional material, it seemed to be of little interest to McCarthy's contemporaries. Reviewers of McCarthy's work made no comment about it. Discussion fell rather to the import of his data, and the comparative analysis he undertook, for diffusionist hypotheses. The impact of his findings upon Davidson's assertion that string figures were a 'meaningless' pursuit was not addressed. A review by the American anthropologist Joseph Birdsell provoked an indignant letter from Barbara Lane at the University of Pittsburgh. ${ }^{63}$ Birdsell proposed that

58 Davidson, Aboriginal Australian String Figures, pp. 783-6.

59 McCarthy, 'Dr Davidson and distribution', p. 71.

60 McCarthy, 'String figures of Australia', p. 283.

61 Davidson, Aboriginal Australian String Figures, p. 782.

62 McCarthy, 'The string figures of Yirrkalla', p. 427.

63 Birdsell, J. B. 1962, 'Records of the American-Australian Scientific Expedition to Arnhem Land, Number 2: Anthropology and nutrition, Charles P. Mountford (Ed.) New York: Cambridge University Press, 1960', [review], American Anthropologist, vol. 64, no. 2, p. 412. Lane, 'On string figures', p. 911. 
McCarthy's research, given the large sample size and the argument that the majority of figures were of local genesis, sounded the death knell for 'the little game of using string figures to trace cultural relationships'. An irony here is that in 1995 two contemporary experts on string figures, Honor Maude and Mark A. Sherman, having found that only 10 per cent of the Yirrkala designs could be made from McCarthy's instructions, published a 'major revision' of the techniques for making them. ${ }^{64}$ There are a number of factors that could have contributed to the errors and inconsistencies in McCarthy's published data, but one assumption that can be safely made is that he was not practised in making string figures or recording how to make them. Both are recognised as difficult skills to master.

The written introduction to McCarthy's inventory of data starts with an acknowledgment of the role of his informants, in which they are all identified by name. He paid particular tribute to Ngarrawu, as he did also in an article on string figures in the Australian Museum Magazine:

Na:rau...proved to be a golden goose, to coin a term; a genius with a loop of string. She set a world's record which may never be broken. Of the 212 designs that I collected at Yirrkala Na:rau made all but 10, and fashioned all but 6 of the 187 techniques (or series of manipulations secured). Whether she made the figures slowly for recording purposes or rapidly for photography, her errors were remarkable [sic] low. Her long slim fingers moved gracefully over the strings, like a pianist's over the keys of her piano. Her astoundingly wide knowledge of the designs, sequences of manipulations and subjects is, from the technical and quantitative points of view, proof of a mastery of her craft and of the possession of highly intellectual powers of mental and manual coordination. With Na:rau string-figure-making is an art. ${ }^{65}$

In Yirrkala, McCarthy's main Yolngu interlocutors belonged to two family groups, from two different clans: the Marika family of the Rirratjingu clan and the Maymuru family of the Manggalili clan. Mathaman Marika had provided the Yolngu Matha names for things on McCarthy's list of material culture items, and he accompanied McCarthy and Bill Harney on an excursion to Yalangbara where they documented a cave-painting site (of Mathaman's dreaming story). McCarthy was adopted by Wandjuk Marika as his classificatory 'brother'. He spent one particular morning with Wandjuk, Nanyin and Narratjin Maymuru getting interpretations of bark paintings. 'An interesting day,' he records in his diary. The larger discussion enabled him 'to get an insight into the artists [sic] approach \& composition \& use of colour' ${ }^{66}$ Another day he photographed the

64 Maude and Sherman, 'The string figures of Yirrkala'.

65 McCarthy, 'String figures of Australia', p. 281.

66 McCarthy, 26 August 1948, Diary 5, AMS515, Australian Museum Archives. 
use of a pile house made by Mawalan Marika and his family. (McCarthy had identified Dadaynga or Roy Marika as a particularly skilful exponent of stringfigure making among the men, but he was not able to work with him 'as he was employed by the mission all day'. . $^{67}$ These were the men from whom McCarthy gained his information about string figures and who later, as community leaders negotiating relations with the wider Australian society, saw 'educating Europeans about aboriginal culture' as a strategic tool. ${ }^{68}$ Ngarrawu, through her marriage to Nanyin Maymuru, was part of this social grouping, but as a woman, working as the principal informant/collaborator with a male anthropologist, her role was unique.

For McCarthy, the collection of mounted figures was a way of recording the final design, to which the step-by-step instructions referred. Perhaps understandably, he did not value them as items of material culture in themselves. (Being made of industrially manufactured string, rather than the traditional type made from the inside bark of the kurrajong tree, they were obviously not the authentic artefacts of 'stone-age man'.) He did not include string figures in lists he made of the types of material culture items he wished to acquire. ${ }^{69} \mathrm{He}$ also did not include them in the Ethnology Register, made in the field, in which collected items were inventoried..$^{70}$ Most tellingly, he did not accession them into the Museum's collection on his return, as he did with the other artefacts. ${ }^{71}$ They were kept, but ended up buried under a layer of other unregistered items in the Museum's stores, until unearthed by curator Stan Florek in 1988. ${ }^{72}$

The value of these objects today is different to what it was when McCarthy collected them. Their material status is now paramount. They can be recognised as genuine historical artefacts of cross-cultural encounter and exchange. The product of collaboration between two individuals with different skills, they are representative of an engagement between knowledge systems. They do provide an excellent historical record of the practice of string-figure making in Yirrkala. For the visual anthropologist, the collection invites a semiotic analysis. The representational mode of string figures - as made in any part of the world - has not been adequately fathomed. So the size of the collection, and the extent of the accompanying data, is valuable indeed. It offers the opportunity to understand how string figures function as an aesthetic meaning system - that is, as an art form. ${ }^{73}$

\footnotetext{
67 Ibid., 7 September 1948.

68 See Morphy, H. 1991, Ancestral Connections: Art and an Aboriginal system of knowledge, University of Chicago Press, Ill., and London, p. 17; and also Thomas, this volume.

69 Copies of these lists were kept in his diaries.

70 F. D. McCarthy, 1948, Diary 8, Ethnology Register, Papers of Frederick D. McCarthy, MS3513/14/7, AIATSIS.

71 Konecny, 'Ethnographic artefacts', p. 46.

72 Florek, S. 1993, 'F. D. McCarthy's string figures from Yirrkala: a museum perspective', Records of the Australian Museum, supp. 17, p. 117.

73 See Morphy, H. 2008, Becoming Art: Exploring cross-cultural categories, UNSW Press, Sydney, p. xi.
} 
10. The String Figures of Yirrkala

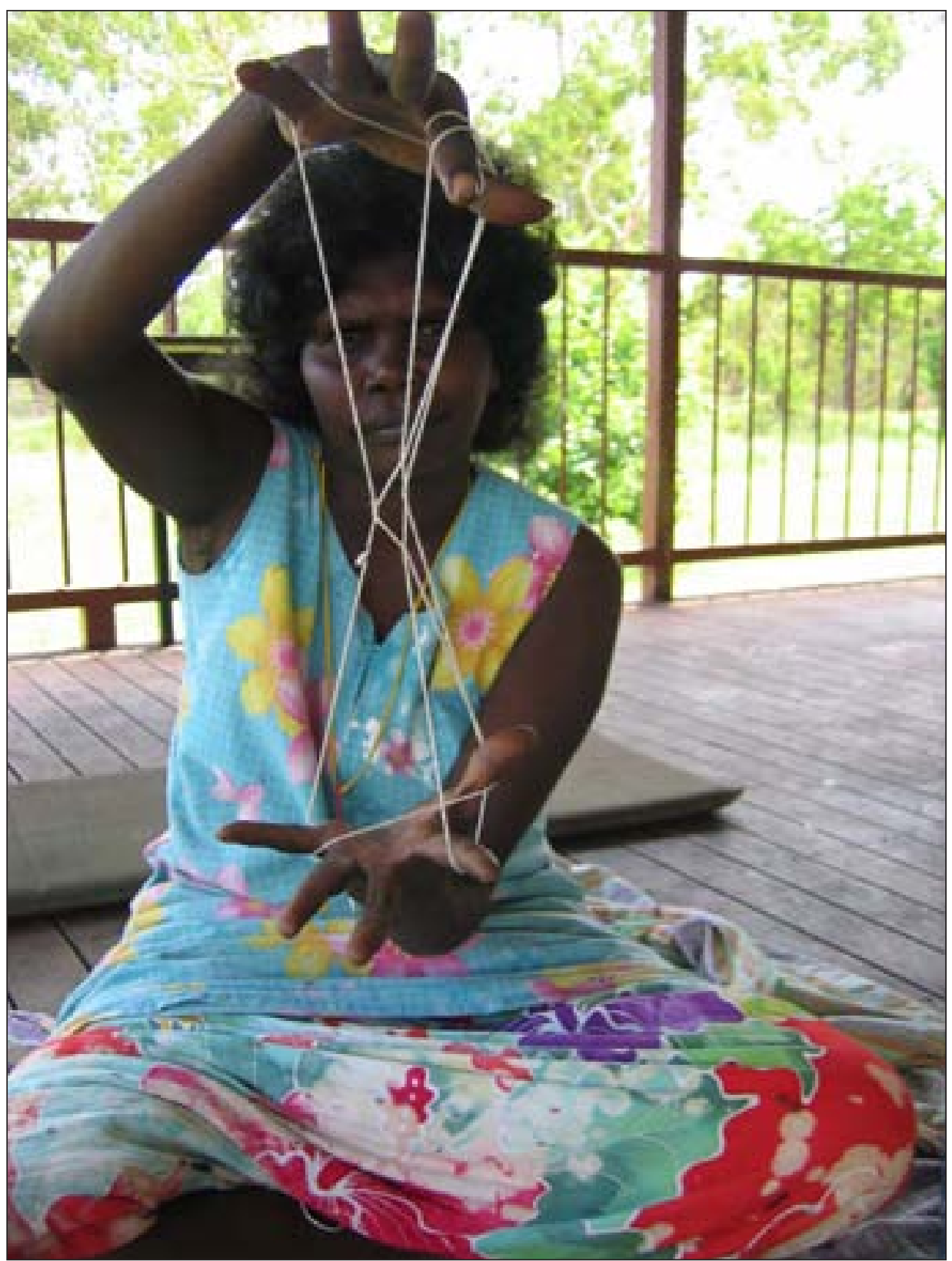

Figure 10.7 Susan Yunupingu demonstrating string-figure technique, Yirrkala, 2009

Photograph by Robyn McKenzie 
Contrary to the expectations of McCarthy and his contemporaries, string-figure making continues in the Yirrkala community today. On my first six-week field trip in 2008-09, I recorded a contemporary repertoire of figures and tricks. McCarthy noted that his interest in matjka-wuma had stimulated enthusiasm for 'the making of them' within the community. ${ }^{74}$ Ngarrawu also gained renown from being considered 'at Yirrkala by her people as the most skilful individual with maitka-uma' ${ }^{75}$ While still practised, string-figure making has not been highly valued as a cultural expression. Wherever it sat in the order of things within the semi-traditional society of 1948, its fate was tied to the community's increasing interaction with the values of a dominant mainstream Australian society. Just as the string figures were not objects that McCarthy could collect as such, it was explained to me that string figures are not something that you can buy and sell - unlike string bags or bark paintings. ${ }^{76}$ After McCarthy, noone wanted string figures from the Yolngu. Unlike other cultural activities, they have no commodity value in the contemporary economy.

What significance the collection holds for today's community is yet to be told. I hope my interest has the same catalytic effect as McCarthy's did-and not just for Yolngu. The final aim of my project is to work in collaboration with the Yirrkala community to bring the string figures 'out of storage' and reanimate them, including telling their story in an exhibition context in which they can be seen, appreciated and experienced as living culture.

\section{Acknowledgments}

I would like to thank my supervisors and other colleagues at the Research School of the Humanities and the Arts at the Australian National University for reading and providing comment on my chapter, as well as the editors of this volume; the staff of the Australian Institute of Aboriginal and Torres Strait Islander Studies Library, Cultural Collections at the Australian Museum and the Australian Museum Archives for their help with access to research collections; and to the Buku-Larrnggay Mulka Art Centre in Yirrkala for facilitating my stay and the Yolngu women I met there for assisting with my research through sharing their knowledge of string figures.

74 McCarthy, 1948, Diary 6, AMS515, Australian Museum Archives.

75 McCarthy, 7 September 1948, Diary 5, AMS515, Australian Museum Archives.

76 Nyalung Wunungmurra in conversation with the author, 12 January 2009. 